\title{
A New Dammarane-type Triterpene with PTP1B Inhibitory Activity from Gynostemma pentaphyllum
}

\author{
Na Li, Zhen-Dong Tuo, Shan-Shan Xing, Shi-Zhou Qi, Hyun-Sun Lee, ${ }^{\dagger}$ and Long Cui* \\ College of Pharmacy, Beihua University, 3999 Binjiangdong Road, Jilin City, Jilin Province 132013, China \\ *E-mail: cuilong71@beihua.edu.cn \\ ${ }^{\dagger}$ Targeted Medicine Research Center, Korea Research Institute of Bioscience and Biotechnology, Chungbuk 363-883, Korea \\ Received June 5, 2014, Accepted June 30, 2014
}

Key Words : Gynostemma pentaphyllum, PTP1B, Dammarane-type triterpene

Gynostemma pentaphyllum (Thunb.) Makino (Cucurbitaceae), a perennial liana herb, is widely cultivated in China, Japan and Korea. It has been traditionally used as medicinal herbs for treatment of cardiovascular disease, hyperlipidaemia, hypertension, hepatitis, diabetes and cancer, ${ }^{1}$ and the biologically active components are believed to be Saponins. ${ }^{2}$ Previous phytochemical studies on $G$. pentaphyllum have been revealed the presence of saponins as well as carotenoids, ${ }^{4}$ flavonoids, ${ }^{5}$ chlorophylls, ${ }^{6}$ lignin, ${ }^{7}$ and polysaccharides. ${ }^{8}$ During the course of our searching for protein tyrosine phosphatase 1B (PTP1B) inhibitors from natural sources, G. pentaphyllum was investigated. From the extract of the root of this plant, a new dammarane-type triterpene named 22(S)-3-oxodammar-20,24-dien-26,22-lactone (1) was isolated, together with six known compounds 24-(Z)-3-oxodammar-20(21),24-dien-27-oic acid (2), 25-methoxy-5 $\alpha$ dammar-20-en-3 $\beta, 24$-diol (3), 24(S)-25-epoxy-5 $\alpha$-protost20,25-dien-3-one (4), (20S,23S)-3 $\beta, 20$-dihydroxyldammarane24-ene-21-oic acid-21,23-lactone (5), 20(S)-dammarane$25(26)$-ene-3 $\beta, 12 \beta, 20$-triol (6), (20S,24S)-dammarane25(26)-ene-3 $\beta, 12 \beta, 20,24$-tetrol (7) (Fig. 1). Herein we reported the isolation, structural elucidation of a new dammaranetype triterpene and evaluation of PTP1B inhibitory activity about these isolates.

\section{Results and Discussion}

Compound 1 was obtained as white solid. Its molecular formula was determined as $\mathrm{C}_{30} \mathrm{H}_{45} \mathrm{O}_{3}$ by HRESIMS. The ${ }^{1} \mathrm{H}$ NMR spectrum of $\mathbf{1}$ showed the presence of six methyl singlets at $\delta 0.91,0.92,0.97,1.02,1.06,1.91$, an oxymethine signal as a doublet of doublets at d $4.75(J=12.4,3.6 \mathrm{~Hz})$, a exomethyene singlets at $\delta 5.22$ and 5.25, and another olefinic signal at $\delta 6.59$ as a broad triplet $(J=6.4 \mathrm{~Hz})$ (Table 1). These data indicated that the structure of 1 might contain terminal olefinic and tri-substituted olefinic groups, which also supported by the presence of four $\mathrm{sp}^{2}$ signals ( $\delta 149.4$, $139.4,128.6$ and 113.7) in ${ }^{13} \mathrm{C}$ NMR spectrum of 1 (Table 1 ). Moreover, the ${ }^{13} \mathrm{C}$ NMR spectrum displayed signals attributed to an oxymethine carbon $(\delta 81.1)$, an ester carbonyl group

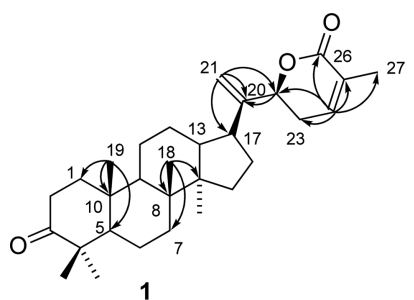

Figure 2. Key HMBC correlations of compound $\mathbf{1}$.
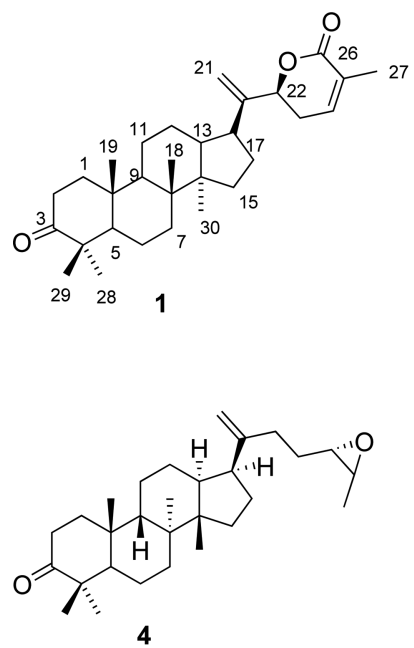

4<smiles>C=C(O)C(C)=CCCC1CCC2C1CCC1C3CC4C(C)C(=O)CCC4(C)C3CCC21C</smiles>

2

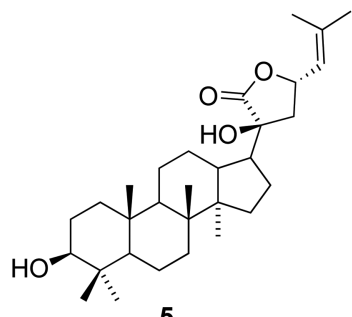<smiles>C=C(CCC(O)C(C)(C)OC)[C@H]1CC[C@@H]2[C@@H]1CC[C@H]1[C@H]2CCC2C(C)(C)[C@@H](O)CC[C@@]21C</smiles>

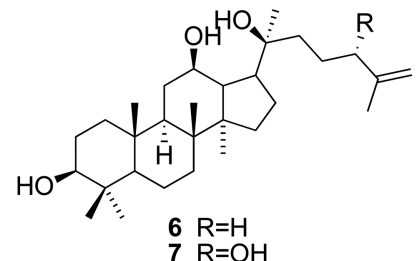

Figure 1. Structures of compounds 1-7. 
( $\delta 166.3)$ and a ketone carbonyl group ( $\delta 218.3)$. In addition, six methyls, ten methylenes, six methines, and eight quaternary carbons were determined by display of its DEPT-135 data. All the above observations and chemical shifts suggested that 1 could be a dammarane-type triterpene. In particular, the ${ }^{1} \mathrm{H}$ and ${ }^{13} \mathrm{C}$ NMR spectra of 1 were in close agreement with those of 24(E/Z)-3-oxodammara-20,24-dien-26al, except for the side-chain moiety. ${ }^{9}$ The presence of an $\alpha, \beta$ unsaturated- $\delta$-lactone moiety was established by observation of the HMBC spectrum data (Fig. 2), which showed long-range correlations from $\delta 4.75(\mathrm{H}-22)$ to $\delta 149.4(\mathrm{C}-20)$ and $113.7(\mathrm{C}-21)$, from $\delta 6.59(\mathrm{H}-24)$ to $\delta 81.1(\mathrm{C}-22), 29.2$ (C-23), 128.6 (C-25), and 166.3 (C-26), from $\delta 5.22,5.25$ $(\mathrm{H}-21)$ to $\delta 149.4(\mathrm{C}-20)$ and $81.1(\mathrm{C}-22)$. The relative stereochemistry of the basic ring moiety was assigned by comparison of chemical shifts with related dammarane-type triterpenes. ${ }^{10}$ The $\delta$-lactone moiety was confirmed the $22 S$ configuration on the basis of a negative Cotton effect at 257 $\mathrm{nm}(\Delta \varepsilon-16.9)$ in the CD spectrum. ${ }^{11}$ Therefore, the structure

Table 1. ${ }^{1} \mathrm{H}(400 \mathrm{MHz})$ and ${ }^{13} \mathrm{C}$ NMR (100 MHz) spectroscopic data of 1 and $2\left(\mathrm{CDCl}_{3}, \delta\right.$, ppm, $\left.J / \mathrm{Hz}\right)$

\begin{tabular}{|c|c|c|c|c|}
\hline \multirow{2}{*}{ Pos. } & \multicolumn{2}{|l|}{1} & \multicolumn{2}{|l|}{2} \\
\hline & $\delta_{\mathrm{H}}(\text { mult }, J \text { in } \mathrm{Hz})^{a}$ & $\delta_{\mathrm{C}}{ }^{a}$ & $\delta_{\mathrm{H}}($ mult, $J$ in $\mathrm{Hz})$ & $\delta_{\mathrm{C}}$ \\
\hline 1 & $1.40, \mathrm{~m}, 1.89, \mathrm{~m}$ & 40.1 & $1.43, \mathrm{~m}, 1.90, \mathrm{~m}$ & 40.1 \\
\hline 2 & $2.32, \mathrm{~m}, 2.46, \mathrm{~m}$ & 34.3 & $2.42, \mathrm{~m}, 2.48, \mathrm{~m}$ & 34.3 \\
\hline 3 & & 218.3 & & 218.5 \\
\hline 4 & & 47.7 & & 47.6 \\
\hline 5 & $1.34, \mathrm{~m}$ & 55.6 & $1.37, \mathrm{~m}$ & 55.5 \\
\hline 6 & $1.45, \mathrm{~m}, 1.54, \mathrm{~m}$ & 19.9 & $1.45, \mathrm{~m}, 1.53, \mathrm{~m}$ & 19.9 \\
\hline 7 & $1.29, \mathrm{~m}, 1.54, \mathrm{~m}$ & 34.6 & $1.29, \mathrm{~m}, 1.55, \mathrm{~m}$ & 34.5 \\
\hline 8 & & 41.0 & & 40.9 \\
\hline 9 & $1.36, \mathrm{~m}$ & 50.5 & $1.39, \mathrm{~m}$ & 50.4 \\
\hline 10 & & 37.1 & & 37.0 \\
\hline 11 & $1.24, \mathrm{~m}, 1.53, \mathrm{~m}$ & 22.7 & $1.23, \mathrm{~m}, 1.23, \mathrm{~m}$ & 22.7 \\
\hline 12 & $1.24, \mathrm{~m}, 1.62, \mathrm{~m}$ & 25.3 & $1.24, \mathrm{~m}, 1.71, \mathrm{~m}$ & 25.2 \\
\hline 13 & $2.11, \mathrm{~m}$ & 45.1 & $2.04, \mathrm{~m}$ & 45.1 \\
\hline 14 & & 50.0 & & 50.1 \\
\hline 15 & $1.24, \mathrm{~m}, 1.57, \mathrm{~m}$ & 33.4 & $1.22, \mathrm{~m}, 1.55, \mathrm{~m}$ & 33.2 \\
\hline 16 & $1.71, \mathrm{~m}, 1.94, \mathrm{~m}$ & 30.5 & $1.80, \mathrm{~m}$ & 28.4 \\
\hline 17 & $2.96, \mathrm{~m}$ & 40.2 & $2.64, \mathrm{~m}$ & 44.0 \\
\hline 18 & $0.97, \mathrm{~s}$ & 15.7 & $0.96, \mathrm{~s}$ & 15.7 \\
\hline 19 & $0.92, \mathrm{~s}$ & 16.2 & $0.91, \mathrm{~s}$ & 16.2 \\
\hline 20 & & 149.4 & & 151.4 \\
\hline 21 & $5.22, \mathrm{~s}, 5.25, \mathrm{~s}$ & 113.7 & $4.88, \mathrm{~s}, 4.93, \mathrm{~s}$ & 109.9 \\
\hline 22 & $4.75, \mathrm{dd}(12.4,3.6)$ & 81.1 & $2.06, \mathrm{~m}, 2.17, \mathrm{~m}$ & 38.1 \\
\hline 23 & $2.31, \mathrm{~m}, 2.53, \mathrm{~m}$ & 29.2 & $2.64, \mathrm{~m}$ & 28.9 \\
\hline 24 & 6.59, br t $(6.4)$ & 139.4 & 6.07, br dd $(7.6,7.2)$ & 146.5 \\
\hline 25 & & 128.6 & & 126.4 \\
\hline 26 & & 166.3 & & 172.9 \\
\hline 27 & $1.91, \mathrm{~s}$ & 17.2 & 1.90, br s & 20.7 \\
\hline 28 & $1.06, \mathrm{~s}$ & 26.9 & $1.06, \mathrm{~s}$ & 26.9 \\
\hline 29 & $1.02, \mathrm{~s}$ & 21.2 & $1.02, \mathrm{~s}$ & 21.2 \\
\hline 30 & $0.91, \mathrm{~s}$ & 17.1 & $0.88, \mathrm{~s}$ & 16.9 \\
\hline
\end{tabular}

${ }^{a}$ Chemical shifts in ppm relative to TMS; coupling constants $(J)$ in Hz. of 1 was determined as 22(S)-3-oxodammar-20,24-dien26,22-lactone.

The known compounds 2-7 were identified as 24-(Z)-3oxodammar-20(21),24-dien-27-oic acid (2), ${ }^{12}$ 25-methoxy$5 \alpha$-dammar-20-en-3 $\beta, 24$-diol (3), ${ }^{13} 24(S)$-25-epoxy-5 $\alpha$-protost-20,25-dien-3-one (4), ${ }^{13} \quad(20 S, 23 S)$-3 $\beta, 20$-dihydroxyldammarane-24-ene-21-oic acid-21,23-lactone $(5),{ }^{14} 20(S)$ dammarane-25(26)-ene-3 $\beta, 12 \beta, 20$-triol $\quad(6),{ }^{15} \quad(20 S, 24 S)$ dammarane-25(26)-ene-3 $\beta, 12 \beta, 20,24$-tetrol $(7)^{15}$ based on the NMR data.

All the isolates were assayed their inhibitory activity against PTP1B using an in vitro assay (Table 2), and RK-682 was used as positive control. ${ }^{16}$ As shown in Table 2, compounds 1, 2 and $\mathbf{4}$ showed potential inhibitory activities of PTP1B with $\mathrm{IC}_{50}$ values ranging from $13.2 \pm 1.9$ to $19.2 \pm$ $2.1 \mu \mathrm{M}$, while the remaining compounds displayed moderate effects. The structure-activity relationships of 1-5 against PTP1B indicated that the presence of a hydroxyl group located at C-3 might be responsible for the decrease of inhibitory activity of these compounds. Among the above isolates, compounds 3-4 were reported for the first time from this plant.

\section{Experimental}

General Experimental Procedures. UV spectra were taken in $\mathrm{MeOH}$ using a Shimadzu spectrophotometer. Nuclear magnetic resonance (NMR) spectra were obtained from a Varian Unity Inova $400 \mathrm{MHz}$ spectrometer using TMS as the internal standard. All accurate mass experiments were performed on a Micromass QTOF (Micromass, UK) mass spectrometer. Column chromatography was conducted using silica gel 60, Sephadex LH-20 and RP-18 for thin-layer chromatography, precoated TLC silica gel $60 \mathrm{~F}_{254}$ plates from Merck were used. HPLC runs were carried out using a Shimadzu System LC-10AD pump equipped with a model SPD-10Avp UV detector, and an Optima $\mathrm{Pak}^{\circledR} \mathrm{C}_{18}$ column $(10 \times 250 \mathrm{~mm}, 10 \mathrm{~mm}$ particle size, RS Tech Korea).

Plant Material. The root of G. pentaphyllum was collected in Xuzhou, Jiangsu province, People's Republic of China, and authenticated by Professor Gao Li (College of Pharmacy, Yanbian University). A voucher specimen of the plant (No. 20101006) was deposited at the College of Pharmacy, Beihua

Table 2. PTP1B inhibitory activity of compounds 1-7

\begin{tabular}{cc}
\hline Compounds & $\mathrm{IC}_{50}(\mu \mathrm{M})^{a}$ \\
\hline $\mathbf{1}$ & $13.2 \pm 1.9$ \\
$\mathbf{3}$ & $15.2 \pm 1.1$ \\
$\mathbf{4}$ & 21.92 .3 \\
$\mathbf{5}$ & $19.2 \pm 2.1$ \\
$\mathbf{6}$ & 23.31 .7 \\
$\mathbf{7}$ & $29.1 \pm 2.2$ \\
$\mathrm{RK}^{-682^{b}}$ & $20.5 \pm 0.7$ \\
\hline
\end{tabular}

${ }^{a} \mathrm{IC}_{50}$ values were determined by regression analyses and expressed as mean \pm SD of three replicates. ${ }^{b}$ Positive control. ${ }^{16}$ 
University, Jilin, China.

Extraction and Isolation. The root $(5.0 \mathrm{~kg})$ of $G$. pentaphyllum was extracted with $\mathrm{MeOH}$ at room temperature for 2 weeks and the solution was concentrated to obtain a crude extract. This extract was suspended in $\mathrm{H}_{2} \mathrm{O}$, partitioned successively with $\mathrm{CHCl}_{3}$ and EtOAc, and then the organic solvents were removed. A portion of the $\mathrm{CHCl}_{3}$-soluble fraction $(10.0 \mathrm{~g})$ was chromatographed over a silica gel column using a gradient of $\mathrm{CHCl}_{3}-\mathrm{MeOH}$ (from 70:1, 50:1, $20: 1$ to $10: 1$ ), and was separated into 10 fractions (Fr.D1Fr.D10). Fr.D4 $\left(\mathrm{CHCl}_{3}-\mathrm{MeOH} 10: 1,1.0 \mathrm{~g}\right)$ was chromatographed over silica gel, eluted with a stepwise gradient of $n$ hexane-EtOAc (from 20:1, 19:1 to 0:1) to afford 10 subfractions (Fr.D4.1-Fr.D4.10). Purification of Fr.D4.4 (110.0 $\mathrm{mg}$ ) by semipreparative HPLC using an isocratic solvent system of $95 \% \mathrm{MeCN}$ in $\mathrm{H}_{2} \mathrm{O}$ over $60 \mathrm{~min}$ to yield compounds $1(4.4 \mathrm{mg})$ and $2(6.4 \mathrm{mg})$. The EtOAc extract $(50.7 \mathrm{~g})$ was subjected to silica gel $\mathrm{CC}$ and eluted with a gradient of $\mathrm{CH}_{2} \mathrm{Cl}_{2} / \mathrm{MeOH}(25: 1,20: 1,15: 1,10: 1$, to $5: 1)$ to yield 5 fractions (Fr.E1-E5). Fr.E2 $(709.0 \mathrm{mg})$ was purified by preparative HPLC using an isocratic solvent system of $75 \% \mathrm{MeCN}$ in $\mathrm{H}_{2} \mathrm{O}$ over 30 min followed by $80 \% \mathrm{MeCN}$ in $\mathrm{H}_{2} \mathrm{O}$ over $70 \mathrm{~min}$ to obtain compounds $5(5.9 \mathrm{mg})$ and $\mathbf{6}(5.1$ $\mathrm{mg}$ ). Fr.E3 (2.2 g) was subjected to an RP-18 column and was eluted with $\mathrm{MeOH}-\mathrm{H}_{2} \mathrm{O}(1: 1,2: 1$, to $10: 1)$ to yield six fractions (Fr.E3.1-Fr.E3.6). The most active fraction, Fr.E3.5 (571.0 mg), was further separated by a silica gel column eluted with $\mathrm{CHCl}_{3}-\mathrm{MeOH}(40: 1,35: 1$, to $10: 1)$ to yield 7 subfractions (Fr.E3.5.1-Fr.E3.5.7). Fr.E3.5.3 was purified by preparative HPLC using an isocratic solvent system of $50 \%$ $\mathrm{MeCN}$ in $\mathrm{H}_{2} \mathrm{O}$ over 50 min obtain compound 3 (3.4 mg). Fr.E3.5.5 was separated by HPLC, using a gradient of 40$50 \% \mathrm{MeCN}$ in $\mathrm{H}_{2} \mathrm{O}$ as the mobile phase to produce compounds $7(3.1 \mathrm{mg})$ and $\mathbf{4}(4.9 \mathrm{mg})$.

Compound 1: White solid; $[\alpha]_{\mathrm{D}}+30^{\circ}\left(c, 0.08, \mathrm{CHCl}_{3}\right) ;{ }^{1} \mathrm{H}$ NMR (400 MHz, $\mathrm{CDCl}_{3}$ ) and ${ }^{13} \mathrm{C} \mathrm{NMR}$ data $(100 \mathrm{MHz}$, $\left.\mathrm{CDCl}_{3}\right)$ spectral data see Table 1; HRESIMS $m / z 453.3363$ $[\mathrm{M}+\mathrm{H}]^{+}\left(\Delta-1.5 \mathrm{mmu}\right.$, calcd for $\left.\mathrm{C}_{30} \mathrm{H}_{45} \mathrm{O}_{3}\right)$.

PTP1B Assay. The enzyme activity was measured using $p$-nitrophenyl phosphate ( $p$ NPP) as described previously. ${ }^{16}$ To Each 96 well (final volume: $100 \mu \mathrm{L}$ ) was added $2 \mathrm{mM}$ $p$ NPP and PTP1B $(0.05-0.1 \mu \mathrm{g})$ in a buffer containing 50 $\mathrm{mM}$ citrate ( $\mathrm{pH}$ 6.0), $0.1 \mathrm{M} \mathrm{NaCl}, 1 \mathrm{mM}$ EDTA, and $1 \mathrm{mM}$ dithiothreitol (DTT), with or without test compounds. Following incubation at $37^{\circ} \mathrm{C}$ for $30 \mathrm{~min}$, the reaction was terminated with $1 \mathrm{M} \mathrm{NaOH}$. The amount of produced $p$ nitrophenol was estimated by measuring the absorbance at $405 \mathrm{~nm}$.

Acknowledgments. This research was supported partly by the grants from the Project Sponsored by the State Education Ministry, Key Laboratory of Natural Resources of Changbai Mountain \& Functional Molecules (Yanbian University, Ministry of Education, China) and Special Funds of Medical Programes of Jilin Province of China (No. YYZX201240).

Supporting Information. The NMR spectral data of compound $\mathbf{1}$ are available as Supporting Information.

\section{References}

1. Lu, H. F.; Chen, Y. S.; Yang, J. S.; Chen, J. C.; Lu, K. W.; Chiu, T. H.; Liu, K. C.; Yeh, C. C.; Chen, G. W.; Lin, H. J.; Chung, J. G. In Vivo 2008, 22, 215.

2. Bai, M. S.; Gao, J. M.; Fan, C.; Yang, S. X.; Zhang, G.; Zheng, C. D. Food Chemistry 2010, 119, 306.

3. Zhang, Z.; Zhang, W.; Ji, Y. P.; Zhao, Y.; Wang, C. G.; Hu, J. F. Phytochemistry 2010, 71, 693.

4. Liu, H. L.; Kao, T. H.; Chen, B. H. Chromatographia 2004, 60, 411.

5. Xie, Z.; Zhao, Y.; Chen, P.; Jing, P.; Yue, J.; Yu, L. Journal of Agricultural and Food Chemistry 2011, 59, 3042.

6. Huang, S. C.; Hung, C. F.; Wu, W. B.; Chen, B. H. Journal of Pharmaceutical and Biomedical Analysis 2008, 48, 105.

7. Wang, X. W.; Zhang, H. P.; Chen, F.; Wang, X.; Wen, W. Y. Chinese Chemical Letters 2009, 20, 589.

8. Yang, X.; Zhao, Y.; Yang, Y.; Ruan, Y. Journal of Agricultural and Food Chemistry 2008, 56, 6905.

9. Chávez, H.; Estévez-Braun, A.; Ravelo, Á. G.; González, A. G. Tetrahedron 1997, 18, 6465.

10. Inada, A.; Somekawa, M.; Murata, H.; Nakanishi, T.; Tokuda, H.; Nishino, H.; Iwashima, A.; Darnaedi, D.; Murata, J. Chem. Pharm. Bull. 1993, 41, 617.

11. Rui, T.; Hong, X.; Li, L. N. Planta. Med. 1991, 57, 87.

12. Torpocco, V.; Chávez, H.; Estévez-braun, A.; Ravelo, Á. G. Chem. Pharm. Bull. 2009, 57, 302.

13. Yodsaoue, O.; Sonprasit, J.; Karalai, C.; Ponglimanont, C.; Tewtrakul, S.; Chantrapromma, S. Phytochem. 2012, 76, 83.

14. Hu, L. H.; Chen, X.; Jiang, H. L.; Yang, Z. Y. CN 101530419A, 2009 [9].

15. Ma, S. G.; Jiang, Y. T.; Song, S. J. Yaoxue Xuebao 2005, 10, 924.

16. Cui, L.; Na, M.; Oh, H.; Bae, E. Y.; Jeong, D. G.; Rhu, S. E.; Kim, S.; Kim, B. Y.; Oh, W. K.; Ahn, J. S. Bioorg. Med. Chem. Lett. 2006, 16, 1426. 